\title{
THE AMMONIA AND UREA CONTENT OF INFANTS' STOOLS
}

\author{
WITH A DESCRIPTION OF METHODS* \\ JAMES L. GAMBLE M.D. \\ BOSTON
}

Since bacteria, like other living cells, require a certain intake of nitrogenous material for the maintenance of the chemical structure of their protoplasm, and many of them are also able to utilize it for their energy needs, it is evident that the mediums in which they grow must contain end products of their nitrogen metabolism. Steps in the utilization of protein by bacteria are not in the gross dissimilar from those of the same process in the complex animal organism. They hydrolyze protein, so far as we know, in exactly the same manner as do the digestive ferments and are able ultimately to split off ammonia from the products of hydrolysis just as this is accomplished somewhere in the body. It is very interesting that besides ammonia another familiar end product of protein metabolism-urea-has been measured in appreciable amounts in cultures of bacteria which are normal or occasional inhabitants of the lower intestinal tract. ${ }^{1}$

The presence of ammonia in the stool may usually be demonstrated by adding water to a sample, making the mixture alkaline with potassium carbonate and then heating gently. The escaping ammonia may be detected by smelling, by the turning blue of a strip of moistened red litmus paper, or by noting the white deposit of ammonium chlorid on a glass rod which has been dipped in hydrochloric acid. The presence of urea is shown by an increase in the ammonia content after adding urease (see below). That all of the ammonia and urea in the stool is produced by bacterial proteolysis is certainly open to question. The intestinal ferments split ammonia from the "amid fraction" of the protein molecule. Whether the small amount thus produced is absorbed before reaching the stool mass in the large intestine is not known. There is also some evidence that ammonia is excreted to a slight extent into the upper part of the intestine and that in some conditions of disease, nephritis, for instance, the amount may be con-

\footnotetext{
* Received for publication March 4, 1915.

* From the wards of the Boston Floating Hospital and from the Children's Department of the Massachusetts General Hospital.

1. Kendall, Arthur I, and Walker, Arthur W.: Determination of Urea Nitrogen in Cultures of Certain Bacteria, Jour. Biol. Chem., August, 1913, p. 277.
} 
siderable. On the other hand, Folin and Denis ${ }^{2}$ by experiments with cats have demonstrated that ammonia is absorbed from the large intestine when it contains feces. They have also found that solutions of urea are rapidly absorbed from an empty large intestine. ${ }^{3}$ Whether urea may under certain conditions be excreted into the intestine is not known. Although the balance between possible excretion and proved absorption of these substances is not known, it is probable that the amounts of ammonia and urea found in the stool represent fairly closely the extent, possibly not the full extent rather than the reverse, of bacterial proteolysis in the large intestine.

That total nitrogen determinations in the stool may contain an error due to loss of ammonia nitrogen from the specimen has been well recognized, and precautions are advised for the prevention of this during the collection, storage and drying of stools. Since the determination of nitrogen balance is often an essential point in metabolism experiments, and since the size of the error which may be caused by the loss of ammonia nitrogen is not at all definitely known, it has seemed to us worth while to determine the usual-and unusualamounts of ammonia which may be found in fresh stools, the pace at which it increases while the stool is stored, and the amount which may be driven off during drying.

It was thought, moreover, that a simple method of determining the ammonia content of fresh stools might be useful in another direction. The necessary ability which bacteria have of metabolizing protein has been given the uncomfortable name "putrefaction." While the digestive ferments do not split protein further than the amino-acid stage, bacteria are able to carry the process to completion by decomposing these Bausteine of the protein molecule. From amino-acids of the aromatic type they produce substances-phenol, indol, skatol, and others-which if absorbed from the intestine are suspected of causing harm to the organism unless it protects itself by conjugating them with sulphuric or glycuronic acid and excreting them as inert estersethereal sulphates, chiefly-in the urine. (It should be mentioned here that although these derivatives of tyrosin, tryptophan, and phenylalanin are not produced by the digestive ferments, it is likely that they are formed within the body during the ultimate catabolism of these amino-acids.) As it would seem fair to take the ammonia content of fresh stools as an index of the extent of intestinal putrefaction, and as the method for determining ammonia in stools described below is rapid and simple, it is suggested that such determinations would be

2. Folin, Otto, and Denis, W.: The Origin and Significance of Ammonia in the Portal Blood, Jour. Biol. Chem., March, 1912, p. 161.

3. Folin, Otto, and Denis, W.: Absorption from the Large Intestine, Jour. Biol. Chem., August, 1912, p. 253. 
useful in the study of cases clinically labeled "intestinal auto-intoxication," "intestinal toxemia," etc.

The literature contains scant information as to the amount of ammonia found in fresh stools. Brauneck, ${ }^{4}$ in 1886 , reported the average amount of ammonia in stools from normal adults to be 0.151 per cent. of the dried stool, and that stools from nephritics contained on the average 0.343 per cent. He used the old Schlösing method for determination of ammonia in the urine. The stool sample was made acid with hydrochloric acid and dried. A hot water digest was made from the powdered stool, and lead acetate added. The filtrate, after setting free the ammonia in it by adding milk of lime, was placed in a flat dish under a bell-jar and over another dish containing fourthnormal sulphuric acid. After five days the ammonia taken up by the sulphuric acid was measured by titration. H. Bartling, ${ }^{5}$ using undried samples in which he set the ammonia free by adding soda and collected it in tenth-normal hydrochloric acid by distilling under vacuum at $42 \mathrm{C}$., found in stools from an adult, on ordinary diet, who was normal except for anemia, an ammonia content of 0.398 per cent. of dried substance. After the addition to the diet of $300 \mathrm{gm}$. calf's thymus the ammonia rose to 0.625 per cent. The total nitrogen in the stool, however, was not increased, so that the ammonia nitrogen in per cent. of total nitrogen rose from 4.9 per cent. when on ordinary diet to 8.3 per cent. when extra protein was given. Both these workers regarded the ammonia found in feces as excreted from the wall of the intestinal tract.

METHODS OF PROCEDURE

Method of Collecting Spcimens. - The baby was placed on a Bradford frame in the manner which has been described by Talbot. ${ }^{6}$ The stools were collected for a period of twenty-four hours, beginning at 9 o'clock in the morning. The receiving cup was inspected at hourly intervals by a nurse, and when found to contain feces was removed and placed directly on ice, another cup taking its place in order to keep the stools as fresh as possible. The urine was collected separately. The determinations for total nitrogen, ammonia, and urea nitrogen were carried out within a few hours after completion of the twenty-four hour collection period.

4. Brauneck, W.: Ueber die Ausscheidung von Ammoniak im Kothe bei Gesunden und Kranken, Mitth. d. Würzburger med. Klin., 1886, ii, 219.

5. Bartling, H.: Ein Beitrag zur Frage der Ammoniak-Ausscheidung in menschlichen Organisms, Zentralbl. f. Stoffw.- u. Verdauungskrankh., 1905, vi, 209, 231.

6. Talbot, Fritz B.: Apparatus for Metabolism Experiments in Male Infants, Jour. Am. Med. Assn., Nov. 27, 1909, p. 1818. 
Method of Analysis.-Total nitrogen: The following modification of Folin's micro-Kjeldahl method for total nitrogen in the urine was devised and found to give very satisfactory results. The twenty-four hour specimen of stool is placed in a weighed dish and thoroughly mixed by stirring and rubbing with a spatula, water being added if necessary. Its weight is then determined and a 2 to $5 \mathrm{gm}$. sample weighed out in a small evaporating dish, over this is poured from 60 to 70 c.c. 20 per cent. sulphuric acid and the dish placed on the water-bath for from one-half to one hour. The resulting digest is then transferred to a 100 c.c. volumetric flask, cooled and made up to the mark with 20 per cent. sulphuric acid. From this two 5 c.c. samples are pipetted into large Jena glass test tubes, and $1 \mathrm{gm}$. potassium sulphate, two drops 10 per cent. copper sulphate and a small pebble added to each. No sulphuric acid need be added as enough is contained in the samples. The tubes are then placed over micro-burners and from this point the determination is carried on as in the method for urine. The digestion mixture shotld be boiled carefully at first in order to avoid driving it very far up the sides of the tubes. Digestion will be found to be complete in twenty or twenty-five minutes. One point which is not quite satisfactory must be mentioned. The preliminary digest often contains minute particles which tend to settle, and for this reason the mixture must be shaken immediately before pipetting the samples. All danger of error may be avoided by carrying out the preliminary digestion in a small Kjeldahl flask over a flame, and this plan must be followed when the stool contains casein curds. It was found, however, that duplicates from the usual type of stool, digested on the water-bath, were in close agreement, and also agreed with the result obtained by carrying through a sample by the regular Kjeldahl method. While no essential advantages can be urged, it will be found that as compared with the usual way of doing Kjeldahls, this modification is shorter and less cumbersome, and where other colorimetric nitrogen determinations are being carried out at the same time, it fits conveniently into laboratory routine. The micro-method can also be very conveniently used for determination of total nitrogen in milk, in which case no preliminary digestion is necessary. The milk is simply diluted until 5 c.c. will contain about $1 \mathrm{mg}$. of nitrogen.

Ammonia Nitrogen: At the suggestion of Dr. Denis, the Folin method for ammonia in the urine was used. Folin and Denis have employed it occasionally for the determination of ammonia in feces in the course of animal experiments. The steps are very simple. A 1 or $2 \mathrm{gm}$. sample of well mixed stool is weighed out on a small bit of oiled paper. The paper and sample are then dropped into a large test-tube, and about 5 c.c. of water added. If the stool is fluid, it is 
weighed in a small porcelain dish and rinsed into the test tube with 5 c.c. of water. A few drops of kerosene and 1 or 2 c.c. of a solution containing 15 per cent. potassium oxalate and 15 per cent. potassium carbonate are then added and the determination carried on as in the method for urine, except that the air current is allowed to run twenty minutes instead of ten. All determinations were made in duplicate and the results averaged. In most of the stools examined the agreement between duplicates was within 3 per cent. Considering that the samples were small and weighed separately on an ordinary inexpensive balance, such a result is satisfactory, and is interesting as showing the very uniform composition of the usual type of infants' stool. Stool containing casein shreds and curds gave a difference between duplicates of from 5 to 10 per cent.

Urea Nitrogen: A 1 or $2 \mathrm{gm}$. stool sample was placed in a large test-tube with 5 c.c. of water, 1 c.c. of 15 per cent. "Arlco-urease" and a few drops of kerosene. It was then stoppered and connected with the compressed air tap and allowed to stand thirty minutes at room temperature with a rather slow air current passing through it, for the purpose of breaking up the stool sample. A receiving tube, containing 2 or 3 c.c. of tenth-normal hydrochloric acid, was of course in position. One or 2 c.c. of the potassium oxalate and carbonate solution were then added through the inlet tube and the blowing resumed vigorously for twenty minutes. From the ammonia nitrogen obtained was subtracted that found in a sample similarly prepared, but without the addition of urease. The difference was regarded as urea nitrogen. That this is the case cannot be accepted without reservation. Marshall ${ }^{7}$ has shown the specific action of urease on urea in the urine. That this holds true among the many nitrogen-containing compounds present in feces is probably the case, but would be an extremely difficult point to prove. Duplicate determinations for urea were found to agree with the same closeness as in the case of ammonia.

\section{RESULTS AND DISCUSSION}

The Usual Ammonia Content of Infants' Stools and Its Relation to the Amount of Protein in the Diet.-In Table 1 are given thirtyseven determinations of total nitrogen and ammonia nitrogen from twenty-four hour stool specimens. It being realized that the dayto-day amount of stool passed must vary considerably, the amounts of nitrogen and ammonia per gram of dried stool are also given. These later figures probably afford a better basis for comparison but are not entirely satisfactory because of being affected by the variable amount

7. Marshall, E. K., Jr.: A Rapid Clinical Method for the Estimation of Urea in the Urine, Jour. Biol. Chem., April, 1913, p. 283. 
TABle 1.-Thirty-Seven Determinations of Total Nitrogen and Ammonia Nitrogen from Twenty-Four-Hour Stool Specimens

\begin{tabular}{|c|c|c|c|c|c|c|}
\hline \multirow[b]{2}{*}{ Number } & \multirow{2}{*}{$\begin{array}{l}\text { Gm. } \\
\text { Protein } \\
\text { per } \\
\text { Kilo in } \\
\text { Food }\end{array}$} & \multicolumn{2}{|c|}{ Nitrogen in Stools } & \multicolumn{2}{|c|}{ Ammonia N. in Stools } & \multirow{2}{*}{$\begin{array}{l}\text { Ammonia } \\
\text { N.: } \\
\text { Total N. } \\
\text { Per Cent. }\end{array}$} \\
\hline & & $\begin{array}{c}\text { Total for } \\
24 \\
\text { Hours } \\
\text { mg. }\end{array}$ & $\begin{array}{c}\text { Per Gm. } \\
\text { Dried } \\
\text { Stool } \\
\text { mg. }\end{array}$ & $\begin{array}{c}\text { Total for } \\
24 \\
\text { Hours } \\
\text { mg. }\end{array}$ & $\begin{array}{c}\text { Per Gm. } \\
\text { Dried } \\
\text { Stool } \\
\text { mg. }\end{array}$ & \\
\hline $\begin{array}{r}13.3 \\
11.4 \\
23.2 \\
19.1 \\
5.1 \\
9.2\end{array}$ & $\begin{array}{l}1.2 \\
1.7 \\
1.8 \\
2.0 \\
2.3 \\
2.4\end{array}$ & $\begin{array}{l}102 \\
218 \\
191 \\
488 \\
298 \\
750\end{array}$ & $\begin{array}{l}53 \\
53 \\
24 \\
44 \\
25 \\
54\end{array}$ & $\begin{array}{r}5 \\
16 \\
21 \\
23 \\
29 \\
47\end{array}$ & $\begin{array}{l}2.4 \\
3.9 \\
2.6 \\
2.1 \\
2.5 \\
3.4\end{array}$ & $\begin{array}{r}5.0 \\
7.9 \\
11.0 \\
4.7 \\
9.7 \\
6.3\end{array}$ \\
\hline $\begin{array}{r}13.1 \\
10.2 \\
1.3 \\
24.1 \\
10.1 \\
6.1 \\
25.1 \\
1.1 \\
18.1 \\
5.2 \\
5.3\end{array}$ & $\begin{array}{l}2.9 \\
2.9 \\
2.9 \\
3.6 \\
3.8 \\
4.1 \\
4.2 \\
4.5 \\
4.6 \\
4.4 \\
4.8\end{array}$ & $\begin{array}{l}360 \\
203 \\
417 \\
216 \\
480 \\
230 \\
312 \\
347 \\
501 \\
427 \\
492\end{array}$ & $\begin{array}{l}63 \\
24 \\
39 \\
42 \\
38 \\
40 \\
58 \\
26 \\
35 \\
39 \\
38\end{array}$ & $\begin{array}{l}19 \\
23 \\
39 \\
16 \\
61 \\
25 \\
31 \\
16 \\
43 \\
53 \\
40\end{array}$ & $\begin{array}{l}3.3 \\
2.7 \\
3.6 \\
3.1 \\
4.8 \\
4.4 \\
5.7 \\
1.2 \\
3.0 \\
4.8 \\
3.1\end{array}$ & $\begin{array}{r}5.3 \\
11.3 \\
9.4 \\
7.4 \\
12.7 \\
11.9 \\
10.0 \\
4.6 \\
8.6 \\
12.4 \\
8.1\end{array}$ \\
\hline $\begin{array}{r}17.1 \\
24.2 \\
24.3 \\
11.1 \\
8.1 \\
4.1 \\
3.1 \\
13.2 \\
19.2 \\
5.4 \\
16.1 \\
11.3 \\
11.2\end{array}$ & $\begin{array}{l}5.0 \\
5.0 \\
5.0 \\
5.2 \\
5.2 \\
5.3 \\
5.3 \\
5.4 \\
5.5 \\
5.9 \\
6.1 \\
6.5 \\
6.6\end{array}$ & $\begin{array}{l}215 \\
384 \\
653 \\
625 \\
417 \\
118 \\
447 \\
305 \\
259 \\
640 \\
202 \\
648 \\
710\end{array}$ & $\begin{array}{l}67 \\
42 \\
53 \\
41 \\
37 \\
29 \\
27 \\
46 \\
67 \\
46 \\
37 \\
43 \\
50\end{array}$ & $\begin{array}{r}17 \\
40 \\
53 \\
49 \\
46 \\
3 \\
67 \\
35 \\
33 \\
61 \\
17 \\
54 \\
72\end{array}$ & $\begin{array}{l}5.3 \\
4.3 \\
4.3 \\
3.2 \\
4.1 \\
0.7 \\
4.0 \\
5.2 \\
9.9 \\
4.4 \\
3.1 \\
3.6 \\
5.0\end{array}$ & $\begin{array}{r}1.9 \\
10.4 \\
8.1 \\
7.9 \\
11.0 \\
2.5 \\
15.0 \\
11.5 \\
12.7 \\
9.5 \\
8.4 \\
8.3 \\
10.1\end{array}$ \\
\hline $\begin{array}{r}5.5 \\
20.2 \\
10.4 \\
10.3 \\
23.3 \\
23.1 \\
23.2\end{array}$ & $\begin{array}{l}7.1 \\
8.0 \\
8.6 \\
8.6 \\
8.9 \\
9.5 \\
9.5\end{array}$ & $\begin{array}{r}1,159 \\
451 \\
298 \\
170 \\
571 \\
1,436 \\
628\end{array}$ & $\begin{array}{r}65 \\
68 \\
93 \\
35 \\
65 \\
126 \\
72\end{array}$ & $\begin{array}{l}85 \\
55 \\
37 \\
11 \\
33 \\
65 \\
63\end{array}$ & $\begin{array}{r}4.7 \\
8.3 \\
11.6 \\
2.2 \\
3.8 \\
5.7 \\
7.2\end{array}$ & $\begin{array}{r}7.3 \\
12.2 \\
12.4 \\
6.5 \\
5.8 \\
4.5 \\
10.0\end{array}$ \\
\hline
\end{tabular}


of fat in the stool. The data are arranged with reference to an increasing protein intake. The babies supplying these specimens were all practically normal, that is, they came to the hospital without history of serious nutritional disturbance and when their food was regulated they gained weight in the normal way. Four of them, Nos. 20.2, 23.1, 23.2, and 24.3, were given buttermilk, and three, Nos. 16.1, 17.1, 19.2, received Eiweiss milk. The rest were on ordinary modifications of cow's milk. In a good many instances several specimens were obtained from the same baby, as is indicated in the number column by recurrence of the same figures in the integral part of the numbers. The age of the babies was between 2 and 10 months. A glance at the table will show that the ammonia content is widely variable but tends to grow larger as the protein intake is increased.

TABLE 2.-Averages of Groups Indicated in Table 1

\begin{tabular}{|c|c|c|c|c|c|c|c|}
\hline \multirow{2}{*}{$\begin{array}{c}\text { No. } \\
\text { Observa- } \\
\text { tions }\end{array}$} & \multirow{2}{*}{$\begin{array}{l}\text { Protein } \\
\text { Gm. } \\
\text { per Kilo } \\
\text { in Food }\end{array}$} & \multirow{2}{*}{$\begin{array}{c}\text { Gm. } \\
\text { Carbo- } \\
\text { hydrate } \\
\text { per Kilo } \\
\text { in Food }\end{array}$} & \multicolumn{2}{|c|}{ Nitrogen in Stools } & \multicolumn{2}{|c|}{ Ammonia N. in Stools } & \multirow[b]{2}{*}{$\begin{array}{l}\text { Ammonia } \\
\text { N.: } \\
\text { Total N. } \\
\text { Per Cent. }\end{array}$} \\
\hline & & & $\begin{array}{c}\text { Total } \\
\text { mg. }\end{array}$ & $\begin{array}{c}\text { Per Gm. } \\
\text { Dried } \\
\text { Stool } \\
\text { mg. }\end{array}$ & $\begin{array}{c}\text { Total } \\
\text { mg. }\end{array}$ & $\begin{array}{c}\text { Per Gm. } \\
\text { Dried } \\
\text { Stool } \\
\text { mg. }\end{array}$ & \\
\hline $\begin{array}{r}6 \\
11 \\
13 \\
7\end{array}$ & $\begin{array}{l}1.9 \\
3.9 \\
5.5 \\
8.6\end{array}$ & $\begin{array}{l}13 \\
13 \\
11 \\
11\end{array}$ & $\begin{array}{l}341 \\
362 \\
432 \\
673\end{array}$ & $\begin{array}{l}42 \\
40 \\
45 \\
76\end{array}$ & $\begin{array}{l}23 \\
33 \\
42 \\
50\end{array}$ & $\begin{array}{l}2.8 \\
3.6 \\
4.4 \\
6.2\end{array}$ & $\begin{array}{l}7.4 \\
9.3 \\
9.5 \\
8.4\end{array}$ \\
\hline 37 & 5.0 & 12 & 443 & 52 & 38 & 4.2 & 9.0 \\
\hline
\end{tabular}

This is very evident in Table 2 , in which the groups indicated in Table 1 are averaged. In the first three groups the total nitrogen per gram dried stool is about the same. Apparently as much as 5.5 gm. protein per kilo is nearly as completely utilized as $1.9 \mathrm{gm}$. It must also be admitted that the increase in ammonia content as more protein is utilized could be interpreted as evidence that the excretion factor may be larger than we are assuming. Except when buttermilk or Eiweiss milk was given, the babies received a usual amount of carbohydrate. The average amount in grams per kilo is given in this table, and will be seen to be nearly the same for the four groups. According to the views of Kendall ${ }^{s}$ based on culture-flask experiments, if a sufficient amount of carbohydrate is available bacteria will utilize it for their vegetative needs and metabolize protein only to the extent necessary for the maintenance of their chemical structure, no matter how

8. Kenđall, Arthur I., and Farmer, Chester J.: Studies in Bacterial Metabolism, viii, Jour. Biol. Chem., October, 1912. 
much of it may be at hand. Interpreting the results presented here in this light, we must assume that when the usual amount of carbohydrate is fed babies, the portion of it escaping absorption and reaching the large intestine is altogether inadequate to supply fuel for the vegetative functions of the bacteria. Kendall's experiments are quite convincing on the point that bacteria prefer to metabolize carbohydrate up to a certain point, rather than the nitrogenous substances contained in bouillon, but whether enough carbohydrate can be given a baby, without overtaking its tolerance for it, to bring about in the lower bowel an imitation of his culture-flask conditions, seems to us problematical. Average figures for the thirty-seven specimens are also presented. It will be seen that the average ammonia nitrogen content was $38 \mathrm{mg}$. or $4.2 \mathrm{mg}$. per gram of dried stool. The highest ten in the series gave an average of $64 \mathrm{mg}$. or $6.8 \mathrm{mg}$. per gram dried stool, and

Table 3.-Average Ammonia Content for Three Groups Arranged According to the Number of Stools Passed

\begin{tabular}{|c|c|c|c|c|c|c|c|}
\hline \multirow[b]{2}{*}{$\begin{array}{l}\text { No. } \\
\text { Observa- } \\
\text { tions }\end{array}$} & \multirow[b]{2}{*}{$\begin{array}{l}\text { Gm. } \\
\text { Protein } \\
\text { in Food } \\
\text { per Kilo }\end{array}$} & \multirow[b]{2}{*}{$\begin{array}{l}\text { Number } \\
\text { of Stools } \\
24 \text { Hours }\end{array}$} & \multicolumn{2}{|c|}{ Nitrogen in Stools } & \multicolumn{2}{|c|}{ Ammonia N. in Stools } & \multirow[b]{2}{*}{$\begin{array}{l}\text { Ammonia } \\
\text { N.: } \\
\text { Total N. } \\
\text { Per Cent. }\end{array}$} \\
\hline & & & $\begin{array}{c}\text { Total } \\
\text { mg. }\end{array}$ & $\begin{array}{c}\text { Per Gm. } \\
\text { Dried } \\
\text { Stool } \\
\text { mg. }\end{array}$ & $\begin{array}{c}\text { Total } \\
\text { mg. }\end{array}$ & $\begin{array}{c}\text { Per Gm. } \\
\text { Dried } \\
\text { Stool } \\
\text { mg. }\end{array}$ & \\
\hline $\begin{array}{r}9 \\
12 \\
15\end{array}$ & $\begin{array}{l}5.3 \\
5.4 \\
4.9\end{array}$ & $\begin{array}{r}1 \\
2-4 \\
5-10\end{array}$ & $\begin{array}{l}321 \\
322 \\
608\end{array}$ & $\begin{array}{l}46 \\
55 \\
48\end{array}$ & $\begin{array}{l}27 \\
34 \\
48\end{array}$ & $\begin{array}{l}3.3 \\
5.5 \\
3.7\end{array}$ & $\begin{array}{r}7.6 \\
10.0 \\
8.6\end{array}$ \\
\hline
\end{tabular}

the lowest ten $14 \mathrm{mg}$. or $2.3 \mathrm{mg}$. per gram dried stool. The average for ammonia nitrogen in per cent. of total nitrogen was 9.0, and in per cent. of dried stool substance 0.42 .

Ammonia Content in Relation to Number of Stools Passed.-The results were rearranged in three groups according to the number of stools in twenty-four hours. The averages for these groups are given in Table 3. The amount of protein in the food was, in average, about the same in the three groups. It will be seen that the ammonia content increases as the stools become more frequent. That the ammonia per gram dried stool is not higher in the third group than in the second is undoubtedly due to the large amount of unutilized fat in the stools when they are very frequent. The increase in the extent of putrefaction is probably due to the fact that more nitrogenous material escapes absorption, and to the better opportunity for bacterial activity afforded by the more fluid texture of the stools. That constipated stools contain the least ammonia is interesting, because of the prevailing suspicion that constipation is an ally of intestinal putrefaction. 


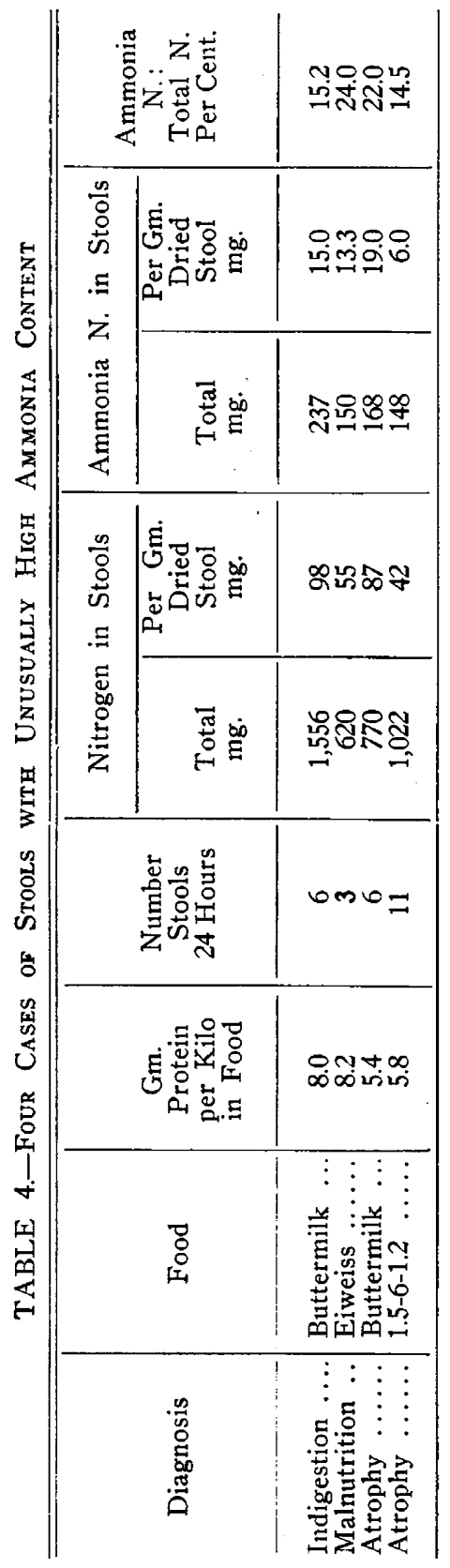


Stools with Unusually High Ammonia Content.-Four such were encountered-see Table 4 . Three were from babies in an advanced stage of malnutrition, the large amount of unutilized protein reaching the lower part of the intestine, as shown by the high nitrogen content of the stools, is probably a sufficient explanation of the unusual degree of putrefaction. It is worth noting, to the discredit of its alleged efficacy in reducing intestinal putrefaction, that two of these babies were receiving buttermilk.

Increase in Ammonia in Stools on Standing.-The extent of this is shown in Table 5. It will be seen there that the amount of ammonia

TABLE 5.-Increase in Ammonia in Stools on Standing

\begin{tabular}{|c|c|c|c|c|c|}
\hline \multicolumn{2}{|c|}{$\mathrm{NH}_{3} \begin{array}{c}\text { Nitrogen Fresh } \\
\text { Stools }\end{array}$} & \multicolumn{2}{|c|}{$\begin{array}{l}\mathrm{NH}^{3} \text { Nitrogen } 24 \text { Hours } \\
\text { After Collection }\end{array}$} & \multicolumn{2}{|c|}{$\begin{array}{l}\mathrm{NH}_{3} \text { Nitrogen } 48 \text { Hours } \\
\text { After Collection }\end{array}$} \\
\hline $\begin{array}{l}\text { Total } \\
\text { mg. }\end{array}$ & $\begin{array}{l}\text { Per Cent. } \\
\text { Total } \\
\text { Nitrogen }\end{array}$ & $\begin{array}{l}\text { Total } \\
\text { mg. }\end{array}$ & $\begin{array}{l}\text { Per Cent. } \\
\text { Total } \\
\text { Nitrogen }\end{array}$ & $\begin{array}{l}\text { Total } \\
\text { mg. }\end{array}$ & $\begin{array}{c}\text { Per Cent. } \\
\text { Total } \\
\text { Nitrogen }\end{array}$ \\
\hline \multicolumn{6}{|c|}{ STOOLS STANDING AT } \\
\hline $\begin{array}{l}26 \\
55 \\
71 \\
40 \\
21 \\
31\end{array}$ & $\begin{array}{r}5 \\
12 \\
5 \\
10 \\
11 \\
10\end{array}$ & $\begin{array}{r}87 \\
167 \\
67 \\
\ldots \\
\ldots\end{array}$ & $\begin{array}{l}19 \\
12 \\
17 \\
\ldots \\
\ldots\end{array}$ & $\begin{array}{r}41 \\
110 \\
212 \\
\because 42 \\
74\end{array}$ & $\begin{array}{r}8 \\
24 \\
15 \\
\dddot{22} \\
24\end{array}$ \\
\hline \multicolumn{6}{|c|}{ STOOLS STANDING IN ICE-BOX } \\
\hline $\begin{array}{l}26 \\
16 \\
54 \\
33\end{array}$ & $\begin{array}{l}5 \\
7 \\
8 \\
6\end{array}$ & $\begin{array}{l}\ldots \\
\cdots \\
\cdots \\
\cdots\end{array}$ & $\begin{array}{l}\ldots \\
\cdots \\
\cdots \\
\ldots\end{array}$ & $\begin{array}{l}31 \\
17 \\
80 \\
35\end{array}$ & $\begin{array}{r}6 \\
8 \\
12 \\
6\end{array}$ \\
\hline
\end{tabular}

found in stools standing at room temperature for forty-eight hours was two or three times as much as the stools when fresh. Stools stored for the same length of time in the ice-chest showed only a very slight increase in the amount of ammonia contained.

Loss of Ammonia from Stools zolite Standing.-Twenty gram samples from six stools were placed in 200 c.c. Erlenmeyer flasks. Each flask was closed by a rubber stopper through which passed two pieces of glass tubing. The outer ends of the tubing were closed by slipping rubber tubing over them and clamping it. The samples were left standing at room temperature for forty-eight hours. The flasks were then connected with the compressed-air tap, and the air inside them driven out, and into a test tube containing a few cubic centimeters 
of tenth-normal hydrochloric acid. Three of the stools were alkaline and three acid. On testing, in each case, the hydrochloric acid in the receiving tube with Nessler's reagent it was found that from two of the alkaline stools a trace of ammonia-not measurable in the colorimeter-had been collected. No ammonia had been given off from the, other four specimens. Evidently then there is not much danger of loss of ammonia from stools stored in closed vessels.

Loss of Ammonia from Stools during Drying.-A ten gm. sample of fresh stool was spread over the bottom of a 200 c.c. Erlenmeyer flask, provided with a rubber stopper carrying inlet and outlet tubes as described as above. The flask was then placed on the water-bath

TABLE 6.-Loss of Ammonia from Stools During Drying

\begin{tabular}{|c|c|c|c|c|c|c|}
\hline \multirow[b]{2}{*}{ Reaction } & \multirow{2}{*}{$\begin{array}{c}\text { Total } \\
\text { Nitrogen } \\
\text { in Fresh } \\
\text { Stool } \\
\text { mg. }\end{array}$} & \multirow{2}{*}{$\begin{array}{c}\text { Ammonia } \\
\text { Nitrogen } \\
\text { in Fresh } \\
\text { Stool } \\
\text { mg. }\end{array}$} & \multicolumn{2}{|c|}{$\begin{array}{l}\text { Ammonia Nitrogen Col- } \\
\text { lected During Drying }\end{array}$} & \multirow{2}{*}{$\begin{array}{c}\text { Nitrogen in } \\
\text { Dried Stool } \\
+ \\
\text { Ammonia } \\
\text { Nitrogen } \\
\text { Collected } \\
\text { mg. }\end{array}$} & \multirow{2}{*}{$\begin{array}{l}\text { Ammonia } \\
\text { Nitrogen } \\
\text { in } \\
\text { Dried Stool } \\
\text { mg. }\end{array}$} \\
\hline & & & $\begin{array}{l}\text { Total } \\
\text { mg. }\end{array}$ & $\begin{array}{l}\text { Per Cent. } \\
\text { Total } \\
\text { Nitrogen }\end{array}$ & & \\
\hline $\begin{array}{l}\text { Alk. } \\
\text { Alk. } \\
\text { Ac. } \\
\text { Ac. } \\
\text { Ac. } \\
\text { Alk. } \\
\text { Alk. } \\
\text { Ac. } \\
\text { Alk. } \\
\text { Ac. } \\
\text { Ac. } \\
\text { Alk. } \\
\text { Alk. } \\
\text { Alk. } \\
\text { Alk. } \\
\text { Alk. }\end{array}$ & $\begin{array}{r}202 \\
1,556 \\
417 \\
710 \\
501 \\
800 \\
648 \\
488 \\
215 \\
295 \\
620 \\
451 \\
628 \\
1,436 \\
653 \\
203\end{array}$ & $\begin{array}{r}17 \\
237 \\
39 \\
72 \\
43 \\
71 \\
54 \\
23 \\
17 \\
50 \\
150 \\
55 \\
63 \\
65 \\
53 \\
23\end{array}$ & $\begin{array}{r}17 \\
341 \\
34 \\
89 \\
9 \\
62 \\
83 \\
6 \\
36 \\
43 \\
89 \\
67 \\
72 \\
42 \\
66 \\
28\end{array}$ & $\begin{array}{r}8.4 \\
21.9 \\
8.2 \\
12.5 \\
1.8 \\
7.8 \\
12.8 \\
1.2 \\
16.8 \\
14.6 \\
14.4 \\
14.9 \\
11.5 \\
2.9 \\
10.1 \\
13.8\end{array}$ & $\begin{array}{r}211 \\
1,562 \\
401 \\
713 \\
498 \\
780 \\
642 \\
486 \\
193 \\
\ldots\end{array}$ & $\begin{array}{r}6 \\
9 \\
18 \\
\\
8\end{array}$ \\
\hline
\end{tabular}

and connected with the compressed-air tap. A slow current of air was allowed to pass through the flask, and then through the tenthnormal hydrochloric acid in a receiving tube, while the stool sample was drying. The ammonia collected in the receiving tube was then measured by adding Nessler's, making up to an appropriate volume and reading in the colorimeter. The results of a series of these experiments are given in Table 6 . The figures for total nitrogen and ammonia nitrogen are for the twenty-four hour specimen. It was found that the acid stools lost a large part of their ammonia, and that from the alkaline stools more ammonia was usually collected than the stools contained before drying. That the cause of this ammonia 
production during drying is bacterial activity does not seem likely as the time required was short-from one and a half to two hoursand the decreasing moisture in the stool unfavorable to bacterial activity. It would seem more probable that the extra ammonia is derived from some nitrogenous substance or substances decomposed by the heat and drying. It is possible that its chief source may be urea. The urea contained in two of the specimens in the series was measured and found to be 20 and $16 \mathrm{mg}$. The extra ammonia collected from these two was 12 and $13 \mathrm{mg}$. A few determinations, given in the last column in the table, showed, that some ammonia was still contained in the dried stool. A comparison of the figures in column 6 in

TABLE 7.-Urea Nitrogen in Fifteen Twenty-Four-Hour Stools

\begin{tabular}{c|c|c|c|c}
\hline \hline $\begin{array}{c}\text { Total } \\
\text { Nitrogen } \\
\text { mg. }\end{array}$ & $\begin{array}{c}\text { Ammonia } \\
\text { Nitrogen } \\
\text { mg. }\end{array}$ & $\begin{array}{c}\text { Urea Nitrogen } \\
\text { Total } \\
\text { mg. }\end{array}$ & $\begin{array}{c}\text { Urea Nitrogen } \\
\text { per gm. } \\
\text { Dried Stool } \\
\text { mg. }\end{array}$ & $\begin{array}{c}\text { Urea N.: } \\
\text { Total N. } \\
\text { Per Cent. }\end{array}$ \\
\hline 170 & 11 & 8 & 1.0 & \\
298 & 37 & 11 & 3.4 & 4.7 \\
295 & 50 & 13 & 1.9 & 4.7 \\
268 & 7 & 15 & 4.4 & 5.6 \\
488 & 23 & 10 & 0.9 & 2.0 \\
259 & 33 & 4 & 1.0 & 0.6 \\
620 & 150 & 24 & 2.1 & 3.9 \\
451 & 55 & 12 & 3.0 & 4.4 \\
1,436 & 65 & 9 & 1.1 & 0.8 \\
191 & 21 & 15 & 1.7 & 4.7 \\
571 & 33 & 9 & 1.8 & 4.6 \\
216 & 16 & 12 & 1.3 & 3.1 \\
384 & 40 & 16 & 1.3 & 2.5 \\
653 & 53 & 31 & 3.0 & 5.1 \\
312 & 31 & & & \\
\hline
\end{tabular}

this table with those in column 2 will show fairly well the degree of accuracy, attained by the micro-Kjeldahl method for total nitrogen.

From these experiments we conclude that there is practically no danger of loss of ammonia nitrogen from stools during collection and storage, unless the specimen is allowed to lose moisture; but that during drying a very serious loss may occur, often as much as from 15 to 20 per cent. of total nitrogen from fresh stools, while from stools left standing for two days at room temperature one half of the total nitrogen may escape measurement. For the prevention of this loss the addition of preservatives is obviously inefficient. The only measure which has a sound basis is the addition of non-volatile acid with the object of fixing the ammonia. This was tested and found to be nearly always completely efficient provided enough acid was thoroughly mixed in the stool. It should be remembered that the texture of the stool 
substance offers obstacles to diffusion and that as its particles dry, ammonia escaping from them may in the absence of water escape contact with the acid. Adding a crystal or two of oxalic acid or a few drops of weak hydrochloric acid is not by any means sufficient, even though this may make the stool acid to litmus. Five c.c. of 2 per cent. hydrochloric acid well mixed with $10 \mathrm{gm}$. of stool was found to prevent any loss of ammonia from stools of the usual type but not from those containing casein shreds and curds. Since the danger of losing nitrogen is entirely avoided by making the determinations from an undried sample we prefer the wet method. We are convinced that as even a sample is obtained from the fresh as from the dried and powdered stool in most instances. There is certainly less chance for error in weighing a 5 to $10 \mathrm{gm}$. sample of fresh stool than comes into the process of grinding up the dried stool, determining its weight and

Table 8.-Increase in Urea in Stools Standing Several Days at ROOM TEMPERATURE

\begin{tabular}{|c|c|c|c|c|}
\hline $\begin{array}{c}\text { Urea N } \\
\text { in Fresh } \\
\text { Stool } \\
\text { mg. }\end{array}$ & $\begin{array}{c}\text { Urea N } \\
24 \text { Hours } \\
\text { After } \\
\text { Collection } \\
\text { mg. }\end{array}$ & $\begin{array}{c}\text { Urea N } \\
48 \text { Hours } \\
\text { After } \\
\text { Collection } \\
\text { mg. }\end{array}$ & $\begin{array}{c}\text { Urea N } \\
\text { Three Days } \\
\text { After } \\
\text { Collection } \\
\text { mg. }\end{array}$ & $\begin{array}{c}\text { Urea N } \\
\text { Five Days } \\
\text { After } \\
\text { Collection } \\
\text { mg. }\end{array}$ \\
\hline $\begin{array}{r}10 \\
20 \\
14 \\
9 \\
12 \\
16\end{array}$ & $\begin{array}{l}\ddot{5} \\
5 \\
. \\
\cdots \\
.\end{array}$ & $\begin{array}{l}13 \\
14 \\
21 \\
26\end{array}$ & $\begin{array}{c}7 \\
\ddot{93} \\
\ldots \\
\ldots \\
\ldots\end{array}$ & $\begin{array}{r}33 \\
122 \\
28 \\
\ldots \\
\ldots\end{array}$ \\
\hline
\end{tabular}

then weighing out a 0.25 to $0.50 \mathrm{gm}$. sample of the dusty hygroscopic powder. Moreover, by the former procedure one escapes the very frequent annoyance of encountering stools which, because of the neutral fat they contain, will not powder, unless they are dried with sea-sand or plaster of Paris, thus introducing another source of error. Even in the case of stools containing much mucus or casein curds we prefer to make a preliminary digest of a large sample and determine the nitrogen in a measured portion of this rather than trust to the evenness of a sample of stool powder.

The Urea Content of Stools.-Urea nitrogen was determined in fifteen twenty-four hour specimens from practically normal babies. The amounts found are given in Table 7 . The average for the fifteen stools was $13 \mathrm{mg}$. or $2.0^{\circ} \mathrm{mg}$. per gram dried stool. The average in per cent. of total nitrogen was 3.5. As may be seen in the table, the proportionate relationship between urea nitrogen and ammonia nitro- 
gen is widely variable. Whether or not some of the urea found in stools was excreted by the intestinal wall, we are unprepared to say. That the intestinal flora are capable of producing urea is evident from an increase in the amount of it found in stools standing several days at room temperature. Determinations showing this are given in Table 8.

Thanks are due to Dr. F. B. Talbot for providing every facility for obtaining material for these experiments from his wards on the Boston Floating Hospital and in the Massachusetts General Hospital, and for his encouraging interest in the results; to Dr. W. Denis for many useful suggestions in the laboratory, and to Miss Visel of the Floating Hospital and Miss Richardson of the Massachusetts General Hospital for their extremely careful supervision of the collection of specimens.

279 Clarendon Street. 